\title{
Enhancement the conditioning of waste activated sludge through a sequence of freeze/thaw-electro-Fenton process
}

\author{
Narjes Shahheidar ${ }^{2}$, Sahand Jorfi, ${ }^{1,2}$, Afshin Takdastan ${ }^{1,2}$, Neemat Jaafarzadeh ${ }^{1,2}$, \\ Mehdi Ahmadi ${ }^{1,2 *}$ \\ ${ }^{1}$ Environmental Technologies Research Center, Ahvaz Jundishapur University of Medical Sciences, Ahvaz, Iran \\ ${ }^{2}$ Department of Environmental Health Engineering, Ahvaz Jundishapur University of Medical Sciences, Ahvaz, Iran \\ "Corresponding author: e-mail: Ahmadi241@gmail.com
}

\begin{abstract}
Sludge conditioning is an important stage in sludge management. In the present study, a sequence of freeze/thaw-electro-Fenton process was designed and specific resistance filtration (SRF) was monitored during sludge conditioning as an important factor in sludge dewaterability. Furthermore, protein and polysaccharide concentrations were measured during the experiments. Results showed that the lowest SRF value contributed to $-10^{\circ} \mathrm{C}$ in freezing process which showed a reducing trend by decreasing solution $\mathrm{pH}$. In addition, results revealed that solution $\mathrm{pH}$ less than 3 caused a significant improvement in sludge dewatering; so the lowest $\mathrm{SRF}$ has been registered at $\mathrm{pH}=2$. By increasing current intensity from 0.5 to $1 \mathrm{~A}$, SRF values were reduced and then followed by an enhancement with increasing current intensity to $3.2 \mathrm{~A}$. The lowest SRF value $\left(6.1 \times 10^{4} \mathrm{~m} / \mathrm{kg}\right)$ was obtained at $\mathrm{H}_{2} \mathrm{O}_{2}=30 \mathrm{mg} / \mathrm{L}$ which was the best conditions for sludge dewatering.
\end{abstract}

Keywords: Sludge conditioning, freeze, thaw, electro-Fenton.

\section{INTRODUCTION}

Nowadays, huge quantities of waste activated sludge (WAS), known as bio-sludge, have been produced from wastewater treatment plants, specifically municipal wastewater treatment plants, which should be properly managed and disposed of low solids, resistant to dewatering increase their operational and economic costs ${ }^{1}$. Dewatering is known as a critical stage in sludge processing which not only decreases the amount of produced sludge, but also leads to decreasing the sludge transportation and disposal expenses. But, bio-sludge process has lots of bonded and hybrid water, which make the dewatering process so difficult. Moreover, extracellular polymeric substances (EPS) are present in varying quantities as the hydrate capsule surrounding the bacterial cell wall and viscous polymers in the activated sludge which lead to huge difficulties in sludge dewatering 1 . Moreover, polysaccharide, protein and DNA, that are the main compounds of EPS, keep water inside them and increase the activated sludge viscosity ${ }^{2,3}$.

It is found that EPS, which contains high amounts of sludge, is a key factor in binding to high quantities of water (i.e., bound water) ${ }^{4,5}$. An EPS network with negative surface charges not only has significant effect on protecting hydrated sludge structure, but also can lead to hampering the release of water and internal substances (e.g., heavy metals) ${ }^{6}$. Consequently, dewatered sludge cake has huge amount of water and high quantity of sludge for disposal ${ }^{6,7,8}$. Hence, EPS destruction and the lysis of sludge microorganisms have been recognized as the critical factors in increasing water discharge from sludge flocs, ${ }^{4,9}$.

Regarding the high stringent disposal regulations, the suitable sludge conditioning processes have to be selected, prior to dewatering ${ }^{10}$ and could be used by various methods of sludge dewatering such as physical conditioning (freeze/thaw and melting and etc.), chemical conditioning (polyelectrolytes, or Fe and $\mathrm{Al}$ salts, Fenton reagents etc.) or by electrochemical conditioning ${ }^{11}$.

It was observed that freeze/thaw conditioning is an efficient physical sludge conditioning approach. The primary aim of this method is that during freezing time, ice crystals grow incorporating water molecules ${ }^{12,13}$. Since the ice crystal structure is quite formed and isochronous, it is not able to carry the extra atoms or molecules. The ice crystals become to amplify since the water molecules are available. All other impurities and solid particles are forced to the boundaries of the ice crystals where they become either compressed or dehydrated. Such method alters sludge flocs into a compacted form, decreases the amount of sludge bound water and improves the sludge quality for settling and filtration ${ }^{7}$. Omerci (2004) reported that an increase in the amount of cations did not lead to the improvement of the freeze-thaw conditioning of activated sludge. Improvement of dewaterability and settleability of activated sludge after freeze-thaw conditioning were declined with an enhancement in the amounts of cations. Moreover, the type of cation would be an effective agent in determination of the efficiency of freeze-thaw conditioning ${ }^{14}$.

Also, Ormeci and Vesilind $(2001)^{15}$ studied the role of freeze/thaw conditioning on alum sludge and waste activated sludge and concluded that freeze/thaw conditioning effectively dewatered alum and activated sludge. However, alum sludge was likely to freeze/thaw better than activated sludge, due to its low dissolved ion and organic matter content. The large amounts of dissolved ions and organic substances in waste activated sludge not only led to the improvement of trapping fine particles during freezing, but also declined the efficiency of freeze/ thaw conditioning ${ }^{16}$.

The Fenton reaction causes dissociation of oxidant and formation of highly reactive hydroxyl radicals that attack and destroy the organic components like EPS which have been discussed and demonstrated to be efficient in the process of sludge dewatering. Fenton reaction has also 
several important advantages such as short reaction time, iron and $\mathrm{H}_{2} \mathrm{O}_{2}$ are economic and nontoxic and process is easy to run and control ${ }^{17,18}$.

electro-Fenton process is a promising method which is capable of oxidizing the organic compounds. In electro-Fenton, one or both reagents (e.g., $\mathrm{Fe}^{2+}$ and $\mathrm{H}_{2} \mathrm{O}_{2}$ ) of Fenton oxidation are electrochemically generated when $\mathrm{Fe}^{2+}$ is electrochemically generated at anode and $\mathrm{H}_{2} \mathrm{O}_{2}$ is added outside of reactor, hydroxyl radical (HO-) as main product of Fenton process, is generated which non-selectively oxidize the organic compounds with $\mathrm{E}^{0}$ $=2.8 \mathrm{~V}$. Moreover, electro-generated $\mathrm{Fe}^{2+}$ along with hydroxide ions generated at cathode, produce $\mathrm{Fe}(\mathrm{OH})_{3}$ as a coagulant agent which can coagulate different compounds. Indeed, electro-Fenton process is a combination of coagulation and oxidation mechanisms which simultaneously occurs at electrochemical cell. Eqs. ((1)-(4)) present the reactions of electro-Fenton in electrolyte ${ }^{19,20}$.

Anode: $\mathrm{Fe} \rightarrow \mathrm{Fe}^{2+}+2 e^{-}$

Cathode: $2 \mathrm{H}_{2} \mathrm{O}+2 e^{-} \rightarrow 2 \mathrm{OH}^{-}+\mathrm{H}_{2}$

Cathode: $\mathrm{Fe}^{3+}+e^{-} \rightarrow \mathrm{Fe}^{2+}$

Introduced $\mathrm{H}_{2} \mathrm{O}_{2}+\mathrm{Fe}^{2+} \rightarrow \mathrm{HO}+\mathrm{Fe}^{3+}+\mathrm{OH}^{-}$

Since the application of freeze/thaw and Fenton has been studied to date as only efficient process for sludge dewaterability, the aim of this study is applying a sequence of freeze/thaw-electro-Fenton process for dewaterability of waste activated sludge.

\section{MATERIAL AND METHODS}

\section{Chemicals}

$\mathrm{H}_{2} \mathrm{O}_{2}(30 \%)$ for Fenton reaction, Bovine Serum Albumin (BSA) and Coomasie Brilliant Blue (C.B.B) for determination of protein concentration, phenol and $\mathrm{H}_{2} \mathrm{SO}_{4}(98 \%)$ for determination of polysaccharide concentration were purchased from Merck, Co, Germany.

\section{Sampling and characterization of raw sludge}

Waste activated sludge samples (WAS) were collected from sludge recirculation line of Choneibeh wastewater treatment plant (Ahvaz, Iran). For minimizing the activity of microorganisms, the obtained sludge samples were kept at $4^{\circ} \mathrm{C}$ and the experiments were performed in around $24 \mathrm{~h}$. The chemical characteristics of raw WAS including $\mathrm{pH}$, TS (mg/L), TSS (mg/L), SVI (mL/g), COD (mg/L) dissolved iron $(\mathrm{mg} / \mathrm{L})$ and specific resistance to filtration (SRF) were measured, according to standard methods for examination of water and wastewater ${ }^{\mathbf{2 6}}$.

\section{Freeze/thaw conditioning procedure}

Freezing was achieved by floating $100 \mathrm{~mm}$ diameter copper-bottomed containers of waste activated sludge on a subfreezing glycerol bath located in cold room. Bath temperature $\left(-10,-15,-20\right.$ and $\left.-25^{\circ} \mathrm{C}\right)$ was controlled by changing the temperature of the cold room for $36 \mathrm{~h}$. The container was capped with insulation to inhibit freezing from the top down, and rigid insulation was placed around the container to insulate the sides and provide buoyancy. Thaw process was done in room temperature during $10 \mathrm{~h}$. In order to investigate the dewaterability of treated sludge after freezing and tha- wing, SRF was measured by vacuum filtration process. In brief, a treated sludge sample $(100 \mathrm{~mL})$ was poured into a $9 \mathrm{~cm}$ standard Buchner funnel equipped with pre-wetted filter paper $(1.2 \mu \mathrm{m}$ glass fiber filter $)$, and vacuumed for $20 \mathrm{~min}$ with a constant vacuum pressure of $50 \mathrm{kPa}$. The filtrate volume and the filtration time were recorded. Also, the filter paper was analyzed to measure the water content of the trapped sludge cake in the filter ${ }^{21}$. By plotting a straight line of filtrate volume vs. time/volume, SRF value can be calculated as slope of the line and computed by equation $5^{22}$ :

$$
\frac{t}{v}\left(\frac{\mu r w}{2 A^{2} P}\right) v+\frac{\mu R_{f}}{A P}
$$

where, $r$ is specific resistance to filtration $(\mathrm{m} / \mathrm{kg}), P$ is vacuum pressure of filtration $\left(\mathrm{N} / \mathrm{m}^{2}\right), \mu$ is viscosity of filtrate (normally taken as that of water at filtrate temperature) $\left(\mathrm{Ns} / \mathrm{m}^{2}\right), V$ is volume of filtrate $\left(\mathrm{m}^{3}\right), t$ is filtration time $(\mathrm{sec}), w$ is weight of dry solids per volume of filtrate $\left(\mathrm{kg} / \mathrm{m}^{3}\right) A$ is area of the filter paper $\left(\mathrm{m}^{2}\right)$ and $R_{f}$ is resistance of filter medium $(1 / \mathrm{m})$.

\section{Electro-Fenton procedure}

A 1 L cubic glass box with four iron plates in bipolar mode was used as an electro-Fenton reactor to study the enhancement of the dewaterability of WAS. Each plate $(3 \times 15 \mathrm{~cm}$, thickness of $3 \mathrm{~mm})$ was connected parallel to negative or positive polar of a DC power supply (Model: PS 303D) with variable current intensities (0-3.5A).

For each run, 0.6 L of waste activated sludge was introduced in the reactor. The solution was also magnetically stirred during experiment and reaction temperature was kept at $26-28^{\circ} \mathrm{C}$. pH of solution was continuously monitored and adjusted to desired value with $0.5 \mathrm{~N} \mathrm{H}_{2} \mathrm{SO}_{4}$ every $5 \mathrm{~min}$ where the volume of acid was less than $3 \mathrm{~mL}$. All experiments were conducted in batch mode.

Electro-Fenton process was initiated by passing electrical current through iron electrodes which were immerged inside WAS and followed by addition of $\mathrm{H}_{2} \mathrm{O}_{2}$ to the reactor. Operational parameters including $\mathrm{pH}$ (2 to 5), current intensity $(0.5$ to $3.2 \mathrm{~A})$, reaction time (10 to 60 min) and $\mathrm{H}_{2} \mathrm{O}_{2}$ dosages (20 to $100 \mathrm{mg} / \mathrm{L}$ ) were studied consecutively according to one factor at the time experimental design. After each run, SRF was measured based on the vacuum filtration method $22,23,24$.

\section{Analytical methods}

\section{Protein concentration}

According to Bradford method, the Bradford indicator was prepared in 0 to $50 \mathrm{mg} / \mathrm{L}$. $0.2 \mathrm{~mL}$ of each concentration was poured in test tubes and added $5 \mathrm{~mL}$ Bradford indicator. After $15 \mathrm{~min}$, the released EPS and protein dosage in sludge supernatant were determined via a T6 UV-visible spectrophotometer (PGeneral, China). The Coomassie Brilliant Blue G-250 approach with BSA as standard was used to find the concentration of protein at $595 \mathrm{~nm}^{23}$.

\section{Polysaccharide concentration}

According to phenol sulfuric acid method, firstly glucose stock solution (commonly standard material for phenol sulfuric acid method) was prepared and diluted with 
different ratios to obtain 0 to $100 \mathrm{mg} / \mathrm{L}$ concentration solutions. $0.5 \mathrm{~mL}$ of each solution was poured in test tubes and $0.5 \mathrm{~mL}$ phenol solution $5 \% \mathrm{~W} / \mathrm{V}$ and $2.5 \mathrm{~mL}$ sulfuric acid $98 \%$ was added to each tube. After $10 \mathrm{~min}$, the amount of polysaccharides was determined using phenol-sulfuric acid method via glucose as standard and measurement of its absorbance at $490 \mathrm{~nm}^{24}$.

\section{RESULT AND DISCUSSION}

Characteristics of raw waste activated sludge were determined in triplicate and the average values are represented in Table 1.

Table 1. Characteristics of raw waste activated sludge

\begin{tabular}{|l|c|}
\hline Parameter & Value \\
\hline $\mathrm{pH}$ & 6.48 \\
\hline TS $[\mathrm{mg} / \mathrm{L}]$ & 312300 \\
\hline TSS $[\mathrm{mg} / \mathrm{L}]$ & 11100 \\
\hline SVI $[\mathrm{mL} / \mathrm{mg}]$ & 81 \\
\hline Supernatant COD $[\mathrm{mg} / \mathrm{L})]$ & 480 \\
\hline Dissolved iron $[\mathrm{mg} / \mathrm{L}]$ & 0.3 \\
\hline SRF $[\mathrm{m} / \mathrm{kg}]$ & $0.61{ }^{*} 10^{12}$ \\
\hline
\end{tabular}

\section{Effect of freezing temperature on sludge dewatering}

After freeze/thaw conditioning, the structure of sludge flock was changed and became more condensed ${ }^{25,26}$. Increasing floc size caused an improvement in sludge filterability and settling ability ${ }^{27}$ In comparison with SRF value of raw sludge, freeze/thaw conditioning substantially reduced SRF value of treated sludge samples. During freeze/thaw conditioning, sludge dewaterability was increased after $36 \mathrm{~h}$. Freezing rate is an important factor in improvement of freeze/thaw process efficiency. Slow freezing rate led to the considerable enhancement in sludge dewatering ${ }^{28,27,29}$. Decreasing freezing temperature is dealing with an enhancement in freezing rate, thus SRF values of conditioned sludge samples at $-10,-15,-20$ and $-25^{\circ} \mathrm{C}$ were respectively $2.8 \times 10^{6}$, $9.8 \times 10^{6}, 1.5 \times 10^{7}$ and $1.08 \times 10^{8}\left(\mathrm{~m} \cdot \mathrm{kg}^{-1}\right)^{30}$ and the lowest SRF values were observed at $-10^{\circ} \mathrm{C}$; as Tuan and Ormeci reported that low freezing rates caused better sludge dewatering ${ }^{14,16}$. Figure 1a shows SRF values of different freezing temperatures. Figure $1 \mathrm{~b}$ shows protein and polysaccharide concentrations in various freezing temperatures. When freezing temperature decreased, protein and polysaccharide concentrations witnessed an increase in sludge supernatant consequently.

\section{Sludge dewatering through electro-Fenton process}

\section{Effect of pH}

The effect of $\mathrm{pH}$ on SRF values is illustrated in Figure 2a. All samples were tested in constant operational conditions $\left(\mathrm{I}=0.5 \mathrm{~A}, \mathrm{t}=20 \mathrm{~min}, \mathrm{H}_{2} \mathrm{O}_{2}=30\right.$ $\mathrm{mg} / \mathrm{L}$ ). As shown in Figure 2a, SRF values in solution $\mathrm{pH} 2,3,4$ and 5 were $7.34 \times 10^{11}, 7.3 \times 10^{13}, 7.4 \times 10^{13}$ and $9 \times 10^{13} \mathrm{~m} / \mathrm{kg}$, respectively. By reducing acidity, SRF values witnessed a considerable increase. Results showed that $\mathrm{pH}<3$ caused significant improvement in sludge dewatering; so the lowest SRF were observed at $\mathrm{pH}=2$. As $\mathrm{pH}$ is a key parameter during Fenton reaction, in acidic solution, iron acts as a catalyst and resulting in decomposition of $\mathrm{H}_{2} \mathrm{O}_{2}$ and formation of hydroxyl radicals. On the other hand, ferric ions tend to formation of ferric hydroxide at higher $\mathrm{pH}(\mathrm{pH}>$ 4), precipitated which cannot return to $\mathrm{Fe}^{2+}$ leading to the reduction of Fenton oxidation efficiency ${ }^{31,32}$. Also, low $\mathrm{pH}$ levels lead to the separation of EPS from the sludge particles and destruction of this material. These changes decrease bonded water and the stability of cell microorganisms increased flock size and sludge filtration. These phenomena improve sludge compressibility and reduce SRF values ${ }^{20,33}$. Rusong Mo and Wang reported that the reduction peak of SRF and highest dry content of sludge cake were happened in $\mathrm{pH}$ range of 2 to $3^{34,35}$. Protein and polysaccharide concentrations during Fenton reaction are illustrated in Figure 2b. According to the figure, protein and polysaccharide concentrations in $\mathrm{pH}$ 2, 3, 4 and 5 were $0.38,2.46,4.1,6.1$ and $0.42,1.5,2.1$, $3.48 \mathrm{mg} / \mathrm{L}$, respectively. Because of reducing acidity in electro-Fenton reaction, EPS isolated from the bacterial cell was dissolved and protein and polysaccharide concentrations in sludge supernatant were increased and dewaterability was decreased ${ }^{36,37}$.

\section{Effect of current intensity}

The effect of different current intensities ( 0.5 to 3.2 A) on sludge dewatering was shown in Figure 3a. All

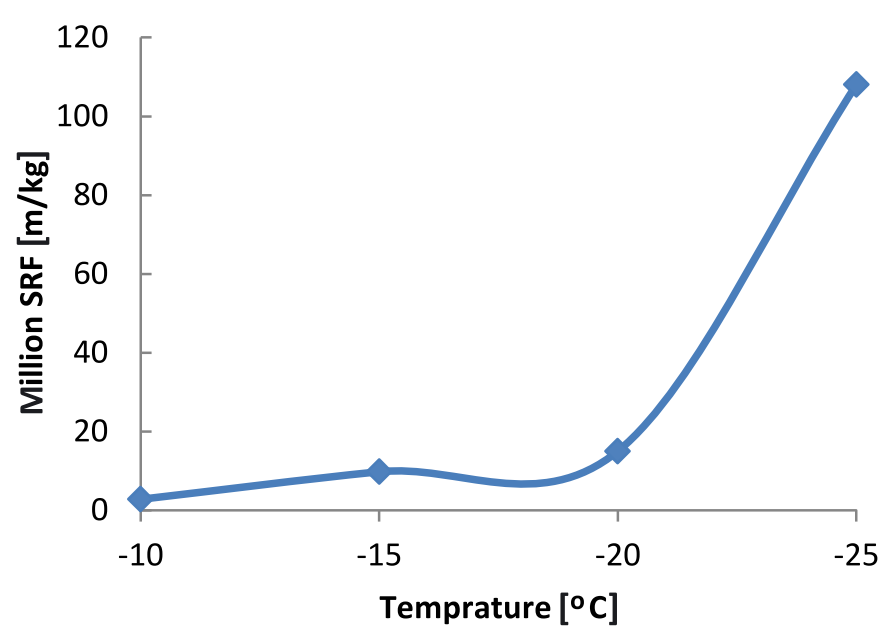

(a)

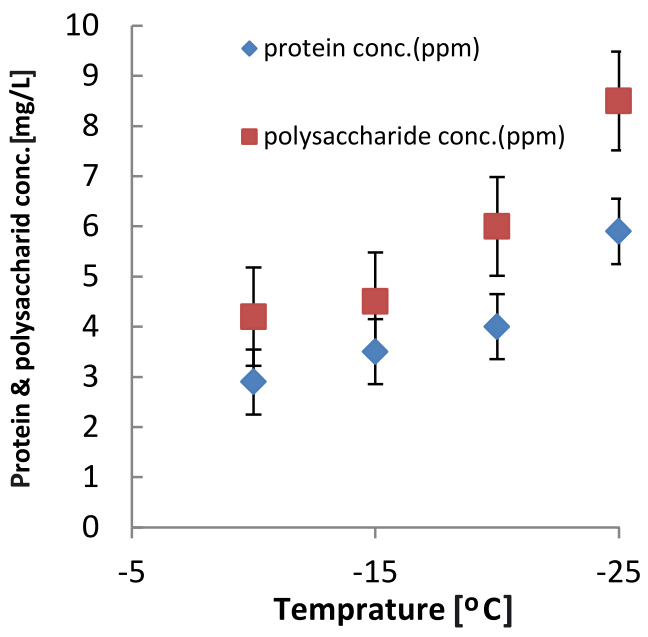

(b)

Figure 1. Effect of freezing temperatures on a) SRF and b) Protein and polysaccharide concentration 


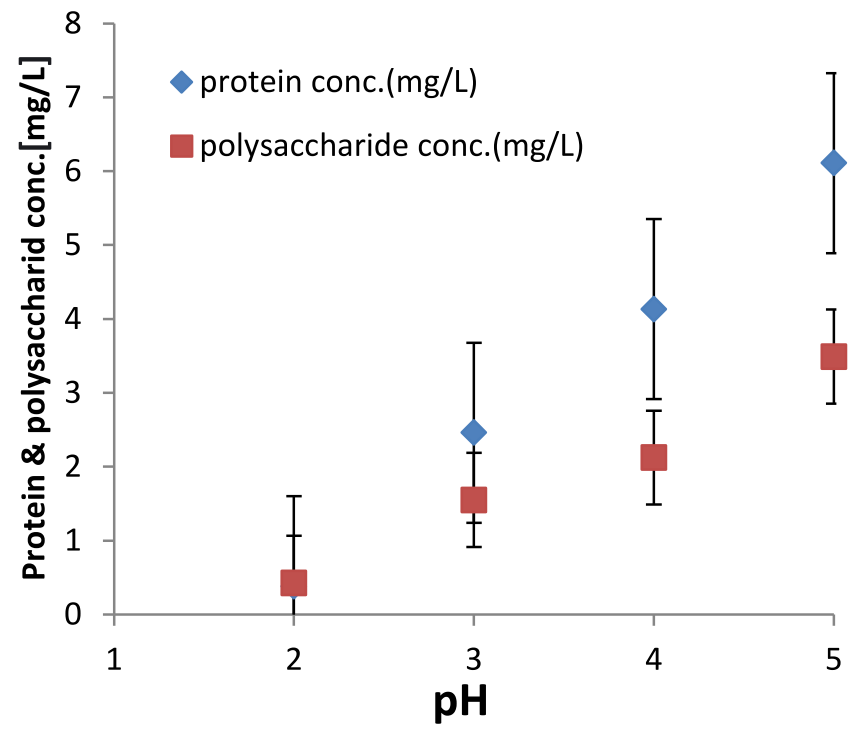

(a)

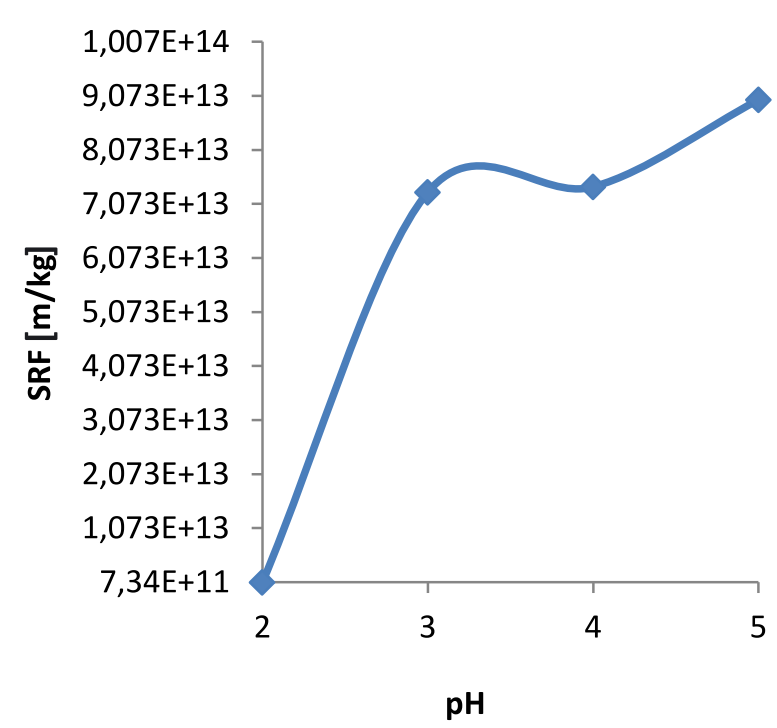

(b)

Figure 2. Effect of pHs on a) $\mathrm{SRF}$ and b) protein and polysaccharide concentrations. $\left(\mathrm{I}=0.5 \mathrm{~A}, \mathrm{t}=20 \mathrm{~min}, \mathrm{H}_{2} \mathrm{O}_{2}=30 \mathrm{mg} / \mathrm{L}\right.$ )

samples were analyzed in constant operational conditions $\left(\mathrm{pH}=2, \mathrm{t}=20 \mathrm{~min}, \mathrm{H}_{2} \mathrm{O}_{2}=30 \mathrm{mg} / \mathrm{L}\right)$. Accordingly, SRF values in current intensities of $0.5,1,2,3$ and 3.2 A were $1 \times 10^{5}, 6.1 \times 10^{4}, 9.31 \times 10^{5}, 9.5 \times 10^{5}$ and $1 \times 10^{6}$ $\mathrm{m} / \mathrm{kg}$, respectively. By increasing current intensity from 0.5 to $1 \mathrm{~A}, \mathrm{SRF}$ values were reduced and then followed by an enhancement with increasing current intensity to above 1 A. Electro-Fenton process, in low current intensities and voltages, led to decomposition of some organic materials and consequently releasing intracellular water. But, increasing current intensity and voltage caused destruction of bacterial cell walls and sludge flocs and their size becomes smaller and created many fine particles in sludge matrices and caused a reduction in sludge dewaterability ${ }^{\mathbf{3 8}}$. It has been hypothesized that current intensity increased ferrous ion production. According to equation 6 , excessive ferrous ions may react with hydroxide radicals and decrease process efficiency ${ }^{39}$.

$$
\mathrm{H}_{2} \mathrm{O}_{2}+\mathrm{OH}^{-} \rightarrow \mathrm{HO}_{2}^{\bullet}+\mathrm{H}_{2} \mathrm{O}
$$

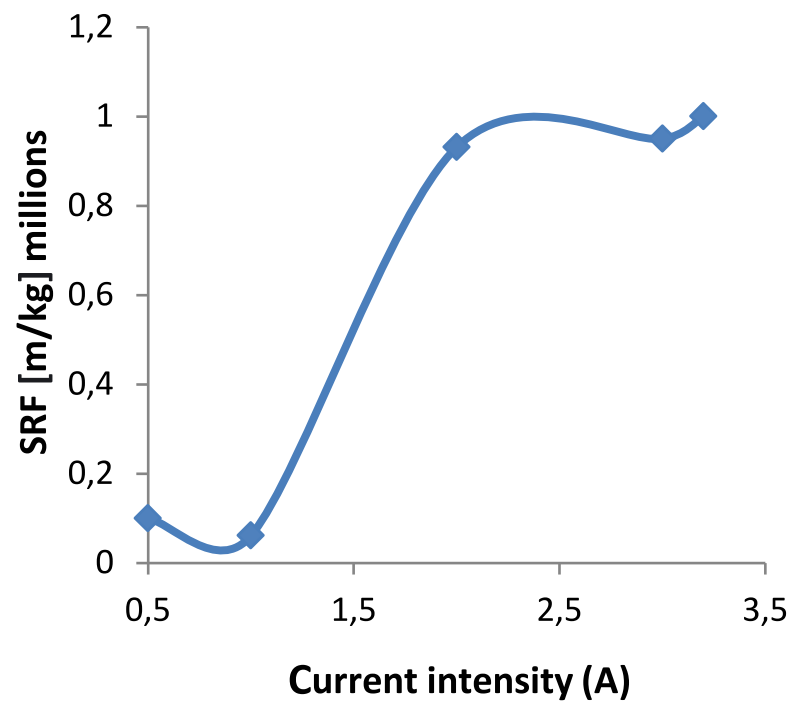

(a)
Figure $3 \mathrm{~b}$ shows the obtained protein and polysaccharide concentrations in different current intensities. According to the Figure, with an enhancement in current intensity from 0.5 to $3.2 \mathrm{~A}$, protein and polysaccharide concentrations were increased from 0 to $5.8 \mathrm{mg} / \mathrm{L}$ and 1.1 to $5.8 \mathrm{mg} / \mathrm{L}$, respectively. When current intensity increased, the bacterial cell was destructed and their intracellular substances was poured out. Consequently, protein and polysaccharide concentrations were increased in supernatant ${ }^{40}$. This fact is in line with the findings of previous research reported by Gharibi et al. (2012) and Yuan et al. $(2011)^{36,40}$.

\section{Effect of reaction time}

Figure 4a illustrates the results of SRF values in various reaction times (10 to $60 \mathrm{~min}$ ). All samples were tested in constant experimental conditions $(\mathrm{pH}=2, \mathrm{I}=1 \mathrm{~A}$, $\left.\mathrm{H}_{2} \mathrm{O}_{2}=30 \mathrm{mg} / \mathrm{L}\right)$. As shown in figure, SRF values were respectively $2.07 \times 10^{5}, 6.1 \times 10^{4}, 7.2 \times 10^{5}, 1.02 \times 10^{6}$ and $1.4 \times 106 \mathrm{~m} / \mathrm{kg}$ during 10 to $60 \mathrm{~min}$. The lowest SRF value

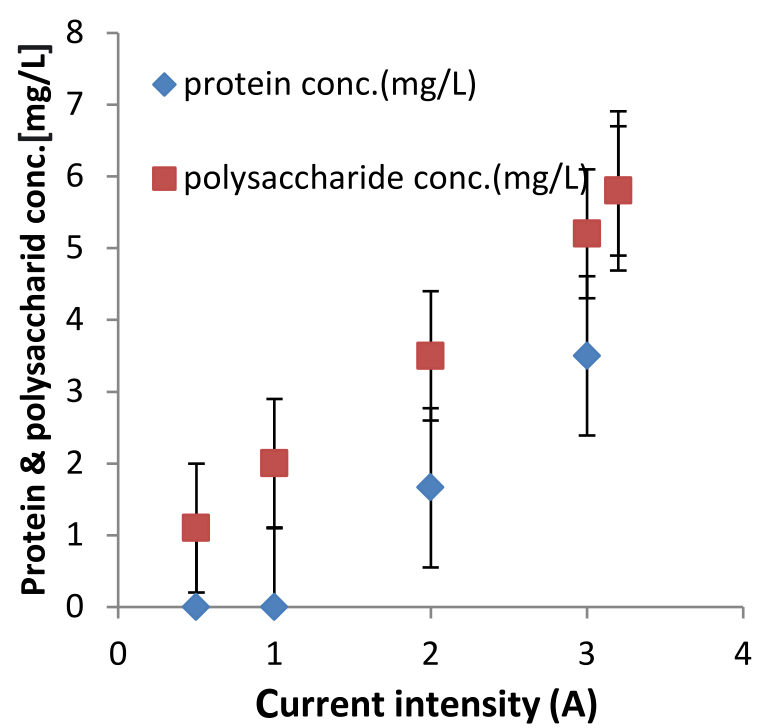

( h)

Figure 3. Effect of current intensity on a) $\mathrm{SRF}$ and b) protein and polysaccharide concentrations. $\left(\mathrm{pH}=2, \mathrm{t}=20 \mathrm{~min}, \mathrm{H}_{2} \mathrm{O}_{2}=\right.$ $30 \mathrm{mg} / \mathrm{L})$ 


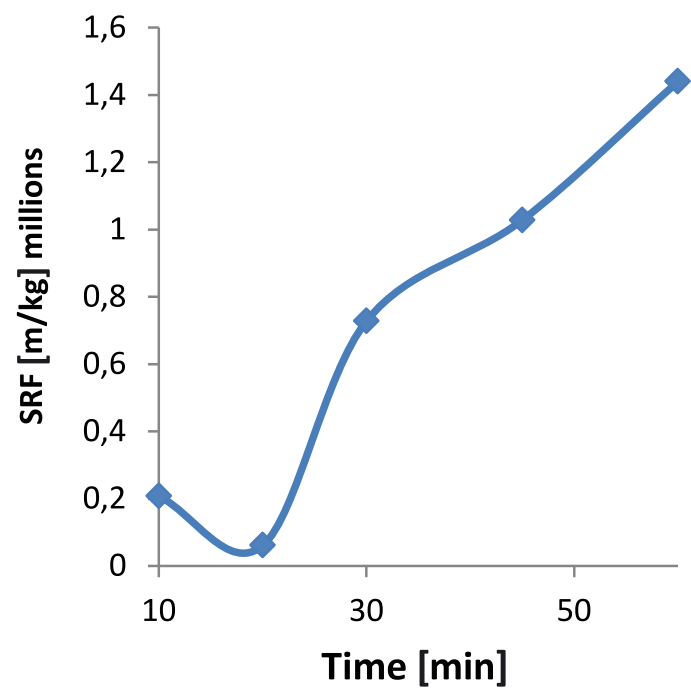

(a)

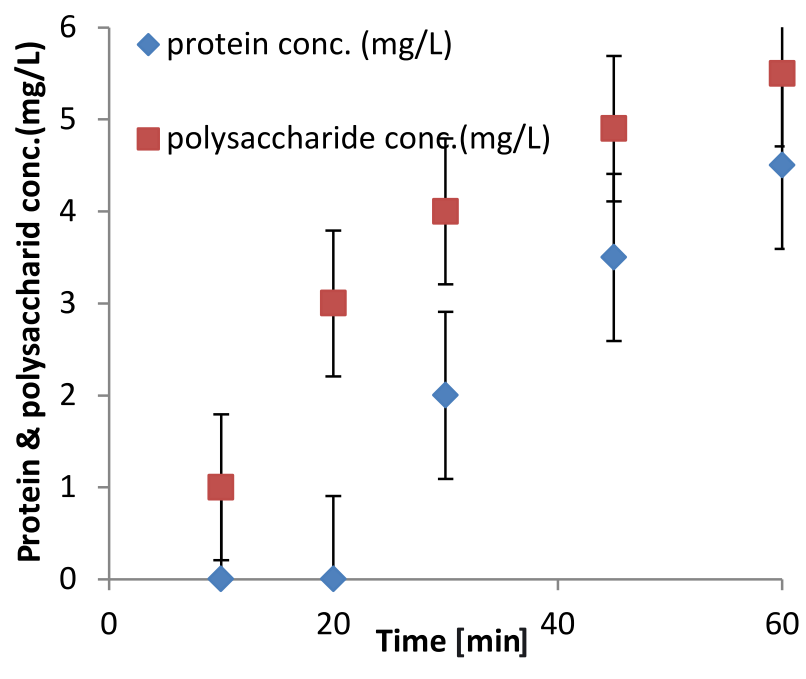

(b)

Figure 4. Effect of reaction times on a) $\mathrm{SRF}$ and b) protein and polysaccharide concentrations. $\left(\mathrm{pH}=2, \mathrm{I}=1 \mathrm{~A}, \mathrm{H}_{2} \mathrm{O}_{2}=\right.$ $30 \mathrm{mg} / \mathrm{L})$

Table 2. Chemical features of raw activated sludge

\begin{tabular}{|l|c|}
\hline Parameter & Value \\
\hline $\mathrm{pH}$ & 6.48 \\
\hline $\mathrm{TS}[\mathrm{mg} / \mathrm{L}]$ & 312300 \\
\hline $\mathrm{TSS}[\mathrm{mg} / \mathrm{L}]$ & 11100 \\
\hline $\mathrm{SVI}[\mathrm{mL} / \mathrm{mg}]$ & 81 \\
\hline Supernatant COD $[\mathrm{mg} / \mathrm{L}]$ & 480 \\
\hline Dissolved iron $[\mathrm{mg} / \mathrm{L}]$ & 0.3 \\
\hline SRF $[\mathrm{m} / \mathrm{kg}]$ & $0.61{ }^{*} 10^{12}$ \\
\hline
\end{tabular}

was obtained at $20 \mathrm{~min}$ contact time. According to the obtained results, sludge dewaterability was improved for 20 min reaction time and SRF value was increased with increasing reaction time. Since electro-Fenton process efficiency depends on reaction time and duration of exposure to electric current, this period should not be either extremely short or long. Furthermore, electro-Fenton process efficiency decreased in long reaction time because of the fact that flocs destroyed with increasing reaction time above $20 \mathrm{~min}$ and created many fine particles in sludge matrices. These phenomena caused difficulties in sludge dewaterability ${ }^{41}$.

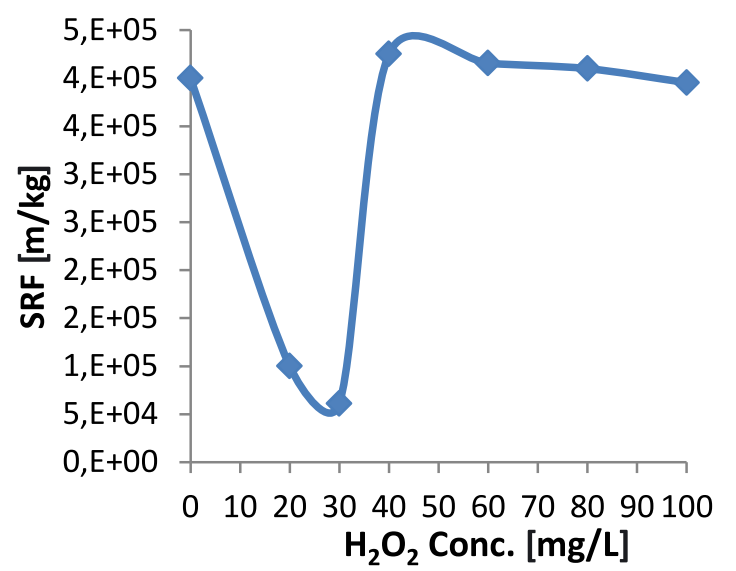

(a)
According to Figure $4 \mathrm{~b}$, the protein and polysaccharide concentrations were increased by increasing reaction time from 10 to $60 \mathrm{~min}$. Bacterial cell wall destruction and sludge flock disintegration were increased with increasing reaction time. Thereupon, intracellular and extracellular biopolymers such as proteins and polysaccharides were released into the soluble phase. The protein and polysaccharide concentrations in sludge supernatant were increased. While sludge flocks were smaller and sludge viscosity experienced an increasing trend. So, dewaterability of sludge became worse ${ }^{36,37,41,40,42}$.

\section{EFFECT OF $\mathrm{H}_{2} \mathrm{O}_{2}$ DOSAGE}

According to Figure 5a, SRF values decreased from $4 \times 10^{5}$ to $6.1 \times 10^{4} \mathrm{~m} / \mathrm{kg}$ by increasing $\mathrm{H}_{2} \mathrm{O}_{2}$ dosage from 0 to $30 \mathrm{mg} / \mathrm{L}$. Also SRF increased from $6.1 \times 10^{4}$ to $3.95 \times 10^{5}$ $\mathrm{m} / \mathrm{kg}$ by increasing $\mathrm{H}_{2} \mathrm{O}_{2}$ dosage from 30 to $100 \mathrm{mg} / \mathrm{L}$. Therefore the lowest SRF value was obtained at $\mathrm{H}_{2} \mathrm{O}_{2}$ concentration of $30 \mathrm{mg} / \mathrm{L}$ which was best condition for sludge dewatering. According to Fenton reaction, the hydroxyl radicals increased by increasing hydrogen

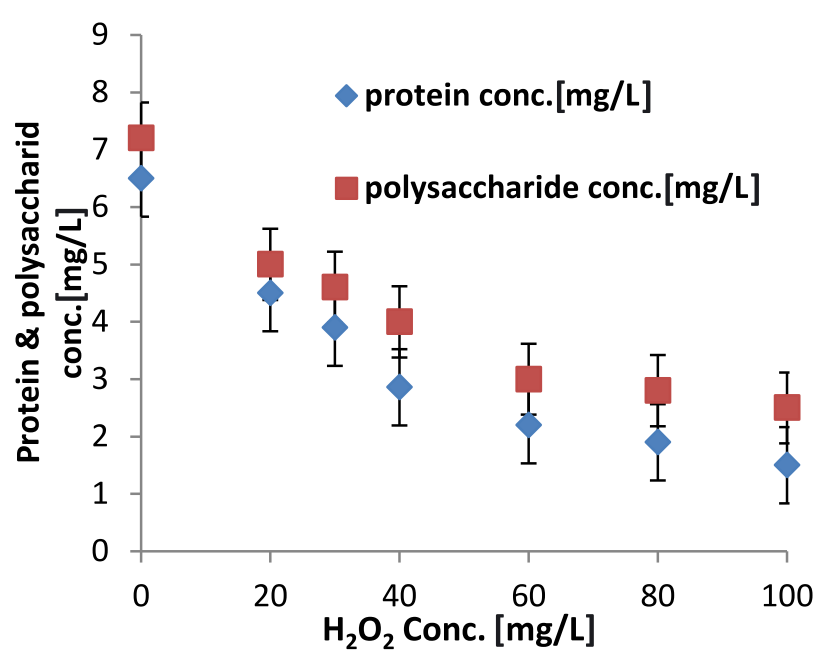

(b)

Figure 5. Effect of $\mathrm{H}_{2} \mathrm{O}_{2}$ concentration on (a) $\mathrm{SRF}$ and b) protein and polysaccharide concentration. $(\mathrm{pH}=2, \mathrm{I}=1 \mathrm{~A}, \mathrm{t}=$ $20 \mathrm{~min}$ ) 
peroxide concentration ${ }^{39}$. These radicals caused EPS destruction and decreasing sludge bonded water which increased sludge flocculation and flock size. Also, the hydroxyl radicals degraded sludge organic matter to $\mathrm{CO}_{2}$, $\mathrm{H}_{2} \mathrm{O}$ and inorganic salts and improved dewaterability and sludge filtration ${ }^{3}$. On the other hand, by increasing $\mathrm{H}_{2} \mathrm{O}_{2}$ dosage above $30 \mathrm{mg} / \mathrm{L}$, SRF values increased to $3.95 \times 10^{6} \mathrm{~m} / \mathrm{kg}$ and also a decrease was happened in sludge dewatering. Because of high values of hydrogen peroxide, hydroxyl radicals reacted with $\mathrm{H}_{2} \mathrm{O}_{2}$ (Eq. 4) and prevented the main reaction between organic materials and hydroxyl radicals ${ }^{39}$.

Introduced $\mathrm{H}_{2} \mathrm{O}_{2}+\mathrm{Fe}^{2+} \rightarrow \mathrm{HO}+\mathrm{Fe}^{3+}+\mathrm{OH}^{-}$

Protein and polysaccharide concentrations are shown in Figure 5b. Accordingly, protein and polysaccharide concentrations, in different $\mathrm{H}_{2} \mathrm{O}_{2}$ concentrations, were $6.5,4.5,3.9,2.86,2.2,1.9,1.5 \mathrm{mg} / \mathrm{L}$ and $7.2,5,4.6,4,3$, $2.8,2.5 \mathrm{mg} / \mathrm{L}$, respectively. Protein and polysaccharide concentrations decreased with increasing $\mathrm{H}_{2} \mathrm{O}_{2}$ dosage which may be derived from the oxidation of extracellular polymeric materials in the presence of $\mathrm{H}_{2} \mathrm{O}_{2}$.

\section{CONCLUSION}

Waste activated sludge management is a costly stage in wastewater treatment plants. Indeed, the application of sludge conditioning process to enhance dewaterability has attracted a great attention in last decades. The obtained results of experiments showed that a sequence of freezing $\left(-10^{\circ} \mathrm{C}\right) /$ thawing (room temperature)/ elctro-Fenton $(\mathrm{pH}$ $=2$, current intensity $=1 \mathrm{~A}$, reaction time $=20 \mathrm{~min}$ and $\mathrm{H}_{2} \mathrm{O}_{2}$ dosage $=30 \mathrm{mg} / \mathrm{L}$ ) was the optimum conditions for best dewaterability enhancement. Electro-Fenton process is a promising technique to enhance dewaterability, due to the onsite generation of iron.

\section{ACKNOWLEDGEMENT}

This work was a part of a funded M.S. thesis of Narjes Shah Heidar. The financial resources of this research were provided by the Environmental Technologies Research Center, Ahvaz Jundishapur University of Medical Sciences (Grant No. ETRC-9312).

\section{LITERATURE CITED}

1. Xinghong Zhang, H.L., Kai, Chen, Zhang, Liu, Han, Wu \& Haiyi, Liang. (2012). Effect of potassium ferrate $\left(\mathrm{K}_{2} \mathrm{FeO}_{4}\right)$ on sludge dewaterability under different $\mathrm{pH}$ conditions. Chem. Eng. J. 210, 467-474. DOI: 10.1016/j.cej.2012.09.013.

2. A.T. Pham, M.S. \& Virkutyte, J. (2010). Sludge dewatering by sand-drying bed coupled with electro-dewatering at various potentials. Int. J. Min. Reclam. Environ. 24, 151-162. DOI: 10.1080/17480930903132620.

3. Elisabeth Neyens, J.B., Raf, Dewil \& Bart, De Heyder. (2004). Advanced sludge treatment affects extracellular polymeric substances to improve activated sludge dewatering. $J$. Hazard. Mater. 106, 83-92. DOI: 10.1016/j.jhazmat.2003.11.014.

4. L.H. Mikkelsen, K.K. (2002). Physico-chemical characteristics of full scale sewage sludge with implications to dewatering. Water Res. 36, 2451-2462. DOI: 10.1016/S0043-1354(01)00477-8.

5. G.P. Sheng, H.Q.Y. \& Li, X.Y. (2010). Extracellular polymeric substances (EPS) of microbial aggregates in biological wastewater treatment systems: a review. Biotechnology $A d v .28$, 882-894. DOI: 10.1016/j.biotechadv.2010.08.001.
6. W.W. Li, H.Q.Y. (2014). Insight into the roles of microbial extracellular polymer substances in metal bio sorption. Bio Res. Technol. 160, 15-23. DOI: 10.1016/j.biortech.2013.11.074.

7. J.H. Bruus, P.H.N. \& Keiding, K. (1992). on the stability of activated - sludge flocks with implications to dewatering. Water Res. 26, 1597-1604. DOI: 10.1016/0043-1354(92)90159-2.

8. X.M. Liu, G.P.S., H.W. Luo, F. Zhang, S.J. Yuan, J. Xu, R.J. Zeng, J.G.,Wu. \& H.Q. Yu. (2010). Contribution of extracellular polymeric substances (EPS) to the sludge aggregation. Environ. Sci. Technol. 44, 4355-4360. DOI: 10.1021/es9016766.

9. Dong-Qin, He, L.F.W., Hong Jiang \& Han-Qing Yu. (2015). A Fenton-like process for the enhanced activated sludge dewatering. Chem. Eng. J. 272, 128-134. DOI: 10.1016/j. cej.2015.03.034.

10. Huan Liu, J.Y., Yafei Shi, Ye Li, Shu He, Changzhu Yang. \& Hong Yao. (2012). Conditioning of sewage sludge by Fenton's reagent combined with skeleton builders. Chemosphere. 88, 235-239. DOI: 10.1016/j.chemosphere.2012.02.084.

11. Izrail, S. \& Turovskiy P.K.M. (2006). Wastewater sludge processing, John Wiley \& Sons, Inc., Hoboken, New Jersey.

12. Kakii, K., Kitamura, S., Shirakashi, T. \& Kuriyama,M. (1985). Effect of calcium ion on sludge characteristics. Ferment Technol. 63, 263.

13. Eriksson L.a.A., B. (1991). Characterization of activated sludge and conditioning with cationic polyelectrolytes. Wat.Sci. Tech. 28, 203. DOI: 10.1016/j.desal.2007.07.016.

14. Ormeci, B. (2004). Freeze-Thaw Conditioning of Activated Sludge: effect of Monovalent, Divalent, and Trivalent Cations. J Resid. Sci. Tech. 3, 143-150. DOI: 1544-8053/04/03.

15. B. Ormeci, P.A.V. (2001). Effect of dissolved organic material and cations on freeze-thaw conditioning of activated and alum sludges. Water Res. 35, 4299-4306. DOI: 10.1016/ S0043-1354(01)00174-9.

16. MS, P.A.T. (2010). Effect of freeze/thaw conditions, polyelectrolyte addition, and sludge loading on sludge electrodewatering process. Chem. Eng. J. 164, 85-91. DOI: 10.1016/j. cej.2010.08.028

17. Esmaeli, R., Hassani, A., Eslami, A., Moghadam, M.A. \& Safari A. (2011). Di-(2-Ethylhexyl) Phthalate oxidative degradation by Fenton process in synthetic and real petrochemical wastewater. Iranian. J. Environ. Health Sci. Eng. 8(3), 201. DOI: $10.1007 / \mathrm{s} 11270-008-9903-9$.

18. Jaafarzadeh, N., Amiri, H. \& Ahmadi, M. (2012). Factorial experimental design application in odification of volcanic ash as a natural adsorbent with Fenton process for arsenic removal. Environ Technol. 33(2), 159-165. DOI: 10.1080/09593330.2011.554887.

19. Ahmadi, M., Amiri, H. \& Martínez, S.S. (2012). Treatment of phenol-formaldehyde resin manufacturing wastewater by the electrocoagulation process. Desalin Water Treat 39(1-3), 176-181. DOI: 10.1080/19443994.2012.669172.

20. Jaafarzadeh, N., Ghanbari, F., Ahmadi, M. \& Omidinasab, M. (2017). Efficient integrated processes for pulp and paper wastewater treatment and phytotoxicity reduction: permanganate, electro-fenton and $\mathrm{Co}_{3} \mathrm{O}_{4} / \mathrm{UV} /$ peroxymonosulfate. Chem. Eng. J. 308, 142-150. DOI: 10.1016/j.cej.2016.09.015.

21. APHA. (2005). Standard Methods for the Examination of Water \& Wastewater (21 th ed). Am. Public Health Assoiation, Washington DC.

22. Shihab, M.S. (2010). Assessment of using chemical coagulants and effective microorganisms in sludge dewaterability process improvement. Environ. Sci. Technol. 3, 35-46. DOI: 10.3923/jest.2010.35.46.

23. J. Kruger, N. (1994). The Bradford method for protein quantitation. Basic protein and peptide protocols. 9-15. DOI: 10.1385/0-89603-268-X:9.

24. Tatsuya Masukoa, A.M., Norimasa Iwasaki, Tokifumi Majima, Shin-Ichiro Nishimura \& Yuan C. Lee. (2005). Carbohydrate analysis by a phenol-sulfuric acid method in micro 
plate format. Anal. Biochem. 339, 69-72. DOI: 10.1016/j. ab.2004.12.001.

25. P.A. Vesilind, S.W. \& Martel, C.J. (1991). Freeze-thaw sludge conditioning and double layer compression. Can. J. Civ. Eng. 18, 1078-1083. DOI: 1139/191-130.

26. T.D. Pham, R.A.S., Virkutyte, J. \& Sillanpa, M. (2009). Combined ultra-sonication and electro kinetic remediation for persistent organic removal from contaminated kaolin. Electrochim. Acta. 54, 1403-1407. DOI: 10.1016/j.electacta.2008.09.015.

27. D.J. Lee, Y.H.H. (1994). Fast freeze/thaw treatment on activated sludge: floc structure and sludge dewaterability. Environ. Sci. Technol. 28, 1444-1449. DOI: 10.1021/es00057a011.

28. W.T. Hung, I.L.C., W.W. Lin. \& D.J. Lee. (1996). Unidirectional freezing of waste activated sludge: effects of freezing speed. Environ. Sci. Technol. 30, 2391-2396. DOI: 10.1021/ es950889x.

29. P.A. Vesilind, C.J.M. (1990). Freezing of water and wastewater sludges. Environ. Eng. Manag. 116, 854-862. DOI: 10.1061/(ASCE)0733-9372(1990)116:5(854).

30. Pham-Anh, Tuana, M.S. (2010). Effect of freeze/thaw conditions, polyelectrolyte addition, and sludge loading on sludge electro-dewatering process. Chem. Eng. J. 164, 85-91. DOI: 10.1016/j.cej.2010.08.028.

31. Xun-an Ning, HC J.W., Yujie Wang, Jingyong Liu \& Meiqing Lin. (2014). Effects of ultrasound assisted Fenton treatment on textile dyeing sludge structure and dewaterability. Chem. Eng. J. 242, 102-108. DOI: 10.1016/j.cej.2013.12.064

32. Chih-Ta Wang, W.L.C. M.H.C. \& Yi-Ming Kuo. (2010). COD removal from real dyeing wastewater by electro-Fenton technology using an activated carbon fiber cathode. Desalination. 253, 129-134. DOI: 10.1016/j.desal.2009.11.020.

33. Neyens, E. B.J. W.M. \& De heyder, B. (2003). Pilot-scale peroxidation $\left(\mathrm{H}_{2} \mathrm{O}_{2}\right)$ of sewage sludge. J. Hazard. Mater. 98, 91-106. DOI: 10.1016/S0304-3894(02)00287-X.

34. Rusong, Mo S.H. W.D., Jialin Liang \& Shuiyu Sun. (2015). A rapid Fenton treatment technique for sewage sludge dewatering. Chem. Eng. J. 269, 391-398. DOI: 10.1016/j. cej.2015.02.001.

35. Tatsuya Masukoa, AM N.I., Tokifumi Majima \& Shin-Ichiro Nishimura, Y.L. (2005). Carbohydrate analysis by a phenol-sulfuric acid method in micro plate format. Anal. Biochem. 339, 69-72. DOI: 10.1016/j.ab.2004.12.001.

36. Hai-ping Yuan XfY C.f.Y. \& Nan-wen Zhu. (2011). Enhancement of waste activated sludge dewaterability by electro-chemical pretreatment. J. Hazard. Mater. 187, 82-88. DOI: 10.1016/j.jhazmat.2010.12.106.

37. Hai-ping Yuan XbC S.p.C., Nan-wen Zhu \& Zhen-ying Zhou. (2011). New sludge pretreatment method to improve dewaterability of waste activated sludge. Bioresour. Technol. 102, 5659-5664. DOI: 10.1021/es1000209.

38. Pham, A.T. (2010). sewage sludge electro dewatering. Int. J. Min. Reclam. Environ. 24, 151-162. DOI: 10.1080/07373937.2012.654874.

39. Eslami, A., Moradi, M., Ghanbari, F. \& Raei Shaktaee, H. (2013). Study on Performance of Electro-Fenton for Color Removal from Real Textile Wastewater Based on ADMI. Color Sci. Technol. 7, 173-180.

40. Gharibi, H., Sowlat, M.H., Mahvi, A.H., Keshavarz, M., Safari, M.H., Bahram Abadi, M. \& Alijanzadeh, A. (2012). Performance evaluation of a bipolar electrolysis/electrocoagulation $(\mathrm{EL} / \mathrm{EC})$ reactor to enhance the sludge dewaterability. Chemosphere. 69, 1-8. DOI: 10.1016/j.chemosphere.2012.09.069.

41. P-ATSMI P. (2012). Sewage Sludge Electro-Dewatering Treatment-A review. Drying Technol. 30, 691-706. DOI: 10.1080/07373937.2012.654874.

42. Haiping, Yuan NZ L.S. (2010). Conditioning of sewage sludge with electrolysis: Effectiveness and optimizing study to improve dewaterability. Bioresour. Technol. 101, 4285-4290. DOI: 10.1016/j.biortech.2009.12.147. 